\title{
Lexicostatistical Studies in East Sudanic II: The Case of Nyimang
}

\begin{abstract}
The paper continues the author's efforts to build up a lexicostatistical basis for the hypothesis of a genetic relationship between several African language groups and families collectively known as «East Sudanic». Here, on the basis of lexical comparison between core basic vocabularies, I argue that the small Nyimang language group of the Nuba Mountains is indeed genetically related to the «core Northeast Sudanic» trio of Nubian, Nara, and Tama, rather than to the much more distantly related Temein languages, also found in the Nuba Mountains. However, this relation may be even more distant than the one between Nubian, Nara, and Tama themselves. Additionally, it is shown that this issue is difficult to resolve without bringing into the comparison at least a limited amount of data from other potentially East Sudanic languages, bringing out the limitations of purely binary (or even ternary) comparison when it comes to establishing the genetic affiliation of small and chronologically remote linguistic entities.
\end{abstract}

Keywords: East Sudanic languages; Nubian languages; Nara language; Nyimang languages; Tama languages; Temein languages; lexicostatistics; basic vocabulary.

\section{Introduction}

In my previous study, published as the first part of a series aimed at redefining the external borders, internal classification, and approximate age of the East Sudanic language family (Starostin 2017), I have conducted a mixed lexicostatistical and etymological analysis of the basic lexicon (50-item wordlist subset) for the Nubian, Nara, and Tama language groups. The conclusion reached was that the evidence was fully supportive of a genetic relationship between these three taxa, albeit one which should probably be regarded as somewhat more distant than genetic relationships between families to which the standard comparative method is applied commonly and efficiently (e.g. Indo-European).

It was also pointed out that this conclusion was in full agreement with the phylogenetic schemes of those linguists who have been, on the whole, supportive of either the East Sudanic or the larger Nilo-Saharan hypothesis, such as M. Lionel Bender, Claude Rilly, and Christopher Ehret (the latter, in his own classification of Nilo-Saharan languages, introduces the term "Astaboran» to denote the unity of Nubian, Tama, and Nara). Beyond that agreement, however, the subsequent genetic connections of the NNT unity remain less certain.

One particular point of minor controversy concerns the status of a very small language group, located in Northern Kordofan and consisting of but two closely related idioms which we shall refer to individually as Ama (endoglossonym; formerly called Nyimang due to geographic localization in the Jebel Nyima mountains) and Dinik (formerly Afitti, based on one of the clan names), and collectively as the Nyimang languages. In Joseph Greenberg's original definition of East Sudanic, this group was simply listed as one out of ten branches of the family (Greenberg 1966: 85). Later on, Bender included it into his «Ek» subgrouping, comprising NNT and Nyimang (Bender 2005: 1); the same subgrouping, dubbed «Northeast Sudanic», was also accepted by Claude Rilly (2009: 44) and Gerrit J. Dimmendaal (2018: 12). On the other hand, Ehret disputes such a classification, placing the Nyimang languages in his classification closer to yet 
another small cluster of Nuba Mountain languages - Temein (Ehret 2001: 70). And, although his opinion seems to be isolated within the small circles of African macro-comparative linguists, it is most likely indicative of unresolved problems and has to be taken into consideration.

In this paper, I would like to further investigate the classificatory hypotheses of Bender and Rilly and extend the methodology that was earlier used to demonstrate the existence of strong links between Nubian, Nara, and Tama to the Nyimang languages. To do that, I shall present a comparison between the reconstructed 50-item wordlists for all four of these subgroups and the respective 50-item wordlist for Nyimang («Proto-Nyimang» where the word in question is attested in both Ama and Dinik and may be reconstructed for the protolevel, or the respective synchronic attestations in Ama and/or Dinik if the two languages exhibit different etymological roots for the same concept).

In addition, I will also take into consideration the corresponding data for Temein languages, for the following reasons: (a) Ehret's alternate hypothesis of a close relationship between Nyimang and Temein deserves at least a quick formal check; (b) if Nyimang and Temein languages are not closely related, they are still geographically adjacent to each other and may share elements of convergent development, which makes it all the more worthwhile to apply lexicostatistical testing to this pair as well, and see if the method actually allows us to distinguish between genetic and areal connections.

\section{General information and data sources}

1. Nyimang. This grouping, as has already been mentioned above, consists of but two languages: Nyimang proper, or Ama, spoken by approximately 70,000 people in Jebel Nyima, and Dinik (Afitti), spoken by only about 4,000 people in the same region (R. Stevenson's estimations circa 1982-84). Geographically, speakers of Nyimang are largely interspersed with speakers of Hill Nubian languages, which makes the issue of their genetic affiliation somewhat more challenging, since, if they do form part of the East Sudanic languages, this would imply the necessity of disentangling Nyimang-Nubian isoglosses inherited from a common ancestor from secondary ones, arising from areal contact.

The first known data on Ama (a list of approximately 40 words in total) were collected by Carl Meinhof and published in his general survey on languages of the Sudan area (Meinhof 1916: 334-335). The first mention of Dinik (Afitti) appears somewhat later, in two papers containing a brief phonetic and grammatical description of the language (Kauczor, Drexel 1930) and an example of a text with translation, but no vocabulary (Kauczor 1923). The first comparative treatment of both languages, showing their close relationship to each other, was performed on the basis of only 19 basic lexemes from each idiom as part of a general comparative survey of languages in the Kordofan area (MacDiarmid, MacDiarmid 1931).

Serious investigation into both languages, however, only begins with the research of Roland C. Stevenson, who spent many years collecting data on various languages of the Nuba Mountains, including Nyimang. His original publications on the subject were largely restricted to a brief grammatical sketch (Stevenson 1957: 171-183), followed by specific papers dealing with various aspects of Nyimang grammar (Stevenson 1981; Stevenson, Rottland, Jakobi 1992). However, already after his death most of his data on the lexicon of Ama and Dinik altogether approximately 550 lexical terms for Ama and slightly fewer for Dinik - were edited and published by M. Lionel Bender (Stevenson 2000); this collection is now our primary source of lexical information on Ama and Dinik, and the data are generally sufficient to extract a near-complete Swadesh wordlist for both languages. 
In more recent times, fieldwork on Nyimang has also been conducted by Claude Rilly (2004-2008), who has published excerpts of his data as part of his attempt at a lexical reconstruction of Proto-Northeast Sudanic (Rilly 2009), and by Alex de Voogt, who has published an updated phonological sketch of Dinik with some new data (Voogt 2009). As of today, however, Stevenson's wordlists, whose phonetic and semantic accuracy seem to be largely vetted by both older and newer fragments of collected data, remain the default data source for any historical research on Nyimang.

The only attempt at a reconstruction of Proto-Nyimang phonology belongs to Rilly (2009: 291-295), who has established (Table 1) the following common phonological inventory for Ama and Dinik (without any significant phonetic change):

\begin{tabular}{c|c|c|c|c}
\hline Labial & Dental & Alveo-dental & Palatal & Velar \\
\hline & ${ }^{*} \mathrm{t}$ & ${ }^{*} \mathrm{t}$ & & ${ }^{*} \mathrm{k}$ \\
\hline${ }^{*} \mathrm{~b}$ & ${ }^{*} \mathrm{~d}$ & ${ }^{*} \mathrm{~d}$ & & ${ }^{*} \mathrm{~g}$ \\
\hline${ }^{*} \mathrm{f}$ & & ${ }^{*} \mathrm{~s}$ & & \\
\hline${ }^{*} \mathrm{w}$ & & ${ }^{*}$ & & \\
\hline & & ${ }^{*} \mathrm{r}$ & & \\
\hline${ }^{*} \mathrm{~m}$ & & ${ }^{*} \mathrm{n}$ & ${ }^{*} \mathrm{n}$ & ${ }^{*} \mathrm{y}$ \\
\hline
\end{tabular}

Table 1. Phonological system (consonants) of Proto-Nyimang (following Rilly 2009)

Vocalic reconstruction remains less certain, but the system is likely to have contained at least five standard phonemes $\left({ }^{*} a,{ }^{*} e,{ }^{*} i,{ }^{*} 0,{ }^{*} u\right)$; more problematic is the issue of reconstructing for Proto-Nyimang +/-ATR-type oppositions such as ${ }^{*} e:{ }^{*} \varepsilon,{ }^{*} 0:{ }^{*} 0$, as well as the distinctive feature of vowel length.

From a typological perspective, the most striking feature of Nyimang which distinguishes it from NNT languages and, conversely, brings it closer to Temein (and «Southeast Sudanic» in general, including such families as Surmic and Nilotic) is the phonological opposition between dental and alveo-dental (alveolar) consonants ${ }^{1}$. On the other hand, the lack of a clearcut distinction between large subsets of +ATR and -ATR vowels is more typical of NNT than «Southeast Sudanic», so even from a purely typological point of view the group presents an interesting case of a potential mixture between genetically inherited and areally obtained features.

Complete Swadesh wordlists for both Ama and Dinik have been extracted from Stevenson's vocabularies (with occasional corroboration of dubious cases based on other available sources), annotated, and published as part of the Global Lexicostatistical Database project (http://starling.rinet.ru/new100). Lexicostatistical calculations show approximately 58\% of direct matches between Ama and Dinik, which yields a glottochronological date of separation at approximately 2600-2800 years BP, about the same time as the disintegration of the Nubian language family.

2. Nubian / Nara / Tama. The exact same data sources are used as in our previous publication on the subject (Starostin 2017); please refer to that publication for details.

${ }^{1}$ It must be noted that de Voogt (2009: 41) notes the lack of a phonological opposition between dental and alveolar consonants in Dinik, rather affirming that the dental and alveolar consonants are typically found in free variation, which further corroborates a similar earlier analysis in Kauczor, Drexel 1930. However, Rilly (2009) confirms that at least in Ama the opposition, as described by Stevenson, is clearly phonological, so the situation in Dinik is probably secondary; it is possible that the original opposition has gradually become neutralized under the linguistic influence of nearby Nubian languages, as well as Arabic. 
3. Temein. Since the Temein languages are not the primary focus of this paper, provided information will be very brief. This small group consists of three closely related languages (Temein proper, or Rongo; Keiga Jirru, or Doni; Tese), spoken in the Western regions of the Nuba mountains. They have mostly been studied by the same researchers who also did work on Nyimang, beginning with the MacDiarmids (1931) and culminating in the studies of Roland C. Stevenson (1957, 1978-1986, 1978-1979, 1988; the latter three references are all to Stevenson's manuscripts containing wordlists for all three languages, made available to the general public through courtesy of Roger Blench).

Relevant phonological descriptions of Temein languages may be found in Stevenson 1957, as well as Yip 2004, the only known important modern work on the phonology of a Temein language (namely, Tese). No attempts at a reconstruction of Proto-Temein phonology have been made, largely because all three phonological systems are extremely close to each other and most of the phonetic differentiation is usually the result of regular or sporadic assimilative processes in the sphere of vocalism. The general system of consonants, on the whole, is not too different from Nyimang, with the exception of the additional presence of a palatal affricate $\left.{ }^{*} z\right)$; the two-way opposition in the sub-system of plosives is described as either an opposition between voiceless phonemes and voiced or implosive phonemes (Stevenson), or as one between positionally conditioned voiceless or voiced phonemes and purely implosive phonemes (Yip). For technical reasons, in our Proto-Temein reconstruction we prefer the solution of Stevenson, reconstructing ${ }^{*} p /{ }^{*} b,{ }_{n}^{*} /{ }^{*} d,{ }^{*} t /{ }^{*} d,{ }^{*} k /{ }^{*} g$ as valid phonological contrasts.

\section{Reconstructed wordlists}

Below (Table 2) we present the standard 50-item subset of the Swadesh wordlist (subscript indexes reflect the «average stability index» of the items as per Starostin 2010) accompanied with the most likely onomasiological reconstructions of the appropriate concepts for:

(a) Nubian / Nara / Tama (NNT). No common NNT reconstruction is provided due to the phonological system of Proto-NNT not having yet been elaborated to general satisfaction. In order to minimize accidental resemblances, we fill in the respective slot only in the presence of a possible isogloss between at least two out of three branches of the taxon, and only when the item in question is formally reconstructible for either ProtoNubian or Proto-Tama (i.e. encountered in more than one branch of the family or is at least present in most languages of the deepest / most archaic branch of that family). Thus, entries for 'black', 'blood', etc. are left empty because all three branches feature unrelated words for these concepts; entry for 'claw/nail', on the other hand, is filled in because Proto-Nubian * suy-di and Proto-Tama * $y o s a$ may be related through metathesis, etc.;

(b) Proto-Nyimang $(\mathrm{N})$. Asterisked reconstructions are provided for cases when the word in question is attested in both descendants; otherwise, Afitti (A) and Dinik (D) forms are listed separately if both are equiprobable to reflect the original Swadesh root for the concept;

(c) Proto-Temein. Asterisked reconstructions are provided for cases when the word in question is attested in at least two out of three languages (as it turns out, for the 50item wordlist this is always the case). Specific forms from Temein languages will be listed and referred to in the comments below if they are relevant to the comparison with Nyimang. 


\begin{tabular}{|c|c|c|c|c|c|c|}
\hline № & Word & NNT & \multicolumn{2}{|c|}{ Nyimang } & Temein & Matches \\
\hline 1 & 'ashes' ${ }_{38}$ & Nu *ubur-ti, TA *or-no & \multicolumn{2}{|c|}{${ }^{*}$ finan } & ${ }^{*} \mathrm{ul}(\mathrm{u})-$ & - \\
\hline 2 & 'bird' & NU *kawir-, NA karba & \multicolumn{2}{|c|}{${ }^{*}$ or-du } & $*=a w \varepsilon$ & $\pm \mathrm{NNT}$ \\
\hline 3 & 'black' 48 & - & \multicolumn{2}{|c|}{$*=$ bi- } & $*=t u+i-$ & - \\
\hline 4 & 'blood' 20 & - & \multicolumn{2}{|c|}{ *ule } & *moni- & - \\
\hline 5 & 'bone' ${ }_{34}$ & $\begin{array}{c}\text { Nu *kəsi-di, NA ketti, } \\
\text { TA *ki-(ya)-ti }\end{array}$ & \multicolumn{2}{|c|}{ *am- } & *am- & $+\mathrm{T}$ \\
\hline 6 & ‘claw/nail' 19 & $\mathrm{NU}^{*}$ sun-di, TA *nosa- (?) & \multicolumn{2}{|c|}{$*_{\text {fal- }}$} & ${ }^{*}=\mathrm{ol}-$ & $\pm \mathrm{T}$ \\
\hline 7 & 'die' ${ }_{13}$ & NU *di:-, NA di:- & \multicolumn{2}{|c|}{ *lu- } & *bu(l)- & - \\
\hline 8 & $\operatorname{dog}_{16}^{\prime}$ & \begin{tabular}{l|l} 
NA wəs, $\mathrm{TA}$ *wes-i & Nu *bəl
\end{tabular} & A gil & D wul & * $=$ we- & $+\mathrm{NNT}$ \\
\hline 9 & 'drink' & NU *ni:-, NA li:-, TA *li- & \multicolumn{2}{|c|}{ A li il } & *awIs- & $+\mathrm{NNT}$ \\
\hline 10 & 'dry' 24 & - & \multicolumn{2}{|c|}{${ }^{*}$ far- } & *ra:ri & - \\
\hline 11 & 'ear's & $\mathrm{NA}^{*}$ tus, $\mathrm{TA} *(\mathrm{y}=)$ us (?) & \multicolumn{2}{|c|}{ *nogor- } & *wen(-a) & - \\
\hline 12 & 'eat' ${ }_{25}$ & NU *kol-, NA kıl- & \multicolumn{2}{|c|}{ *tam- (impf.) / ${ }_{\Gamma}^{*}$ tal- (pf.) } & *lam- & $\pm \mathrm{NNT}$ \\
\hline 13 & 'egg' & Nu *kumbu, TA *kob- & \multicolumn{2}{|c|}{ *dami } & *war- & - \\
\hline 14 & 'eye' $_{4}$ & NU *min-, TA *emen- & & $w)-$ & ${ }^{*}=\mathrm{an}-\sim^{*}=\mathrm{an}-$ & $+\mathrm{T}$ \\
\hline 15 & 'fire' 7 & Nu *usi-gi, TA *us-g & & & *padin & - \\
\hline 16 & 'foot' ${ }_{43}$ & - & & & *=alwa- (?) & - \\
\hline 17 & 'hair' ${ }_{27}$ & - & & & ${ }^{*} z \varepsilon-t_{n}^{-t}$ & $\pm \mathrm{T}$ \\
\hline 18 & 'hand' & $\mathrm{NU}^{*} \partial-\mathrm{si}, \mathrm{NA}$ a:-t, TA *aw-g & & & $*=\varepsilon n(-a)$ & $+\mathrm{NNT}$ \\
\hline 19 & 'head' 49 & $\mathrm{NU}^{*} \mathrm{or}, \mathrm{TA}^{*} \mathrm{ur}$ & & & $*=$ vlo & $+\mathrm{NNT}$ \\
\hline 20 & 'hear' ${ }_{45}$ & $\mathrm{Nu}^{*}$ giz-, TA *sig- (?) & ${ }^{*}$ kic & *kil- & ${ }^{*} \operatorname{ton}^{\mathrm{w}}{ }_{-}$ & - \\
\hline 21 & 'heart' & NA asım-a, TA *samil & & & *om (?) & - \\
\hline 22 & 'horn' 44 & Nu *yəzi, TA *nawi-ti & & & ${ }^{*}$ kini & - \\
\hline 23 & $\mathrm{~T}_{3}$ & Nu *ə-y, NA a-g & & & ${ }^{*} \mathrm{n}=\mathrm{a}-\mathrm{n}$ & $+\mathrm{NNT},+\mathrm{T}$ \\
\hline 24 & 'kill' 42 & NA si:, TA *siy- & & & *tțu & - \\
\hline 25 & 'leaf' ${ }_{41}$ & - & A kwo & D laluwa & *kabo (?) & - \\
\hline 26 & 'louse' ${ }_{17}$ & NA ši-ti, TA *sin- & *nu & $*$ un & - & - \\
\hline 27 & 'meat' 46 & - & & & $*_{\text {ini } \sim * \text { ili }}$ & - \\
\hline 28 & 'moon' 18 & - & & wur & *kaw & $\pm \mathrm{T}$ \\
\hline 29 & 'mouth' & Nu *agul, NA awolo, TA *kul & & & ${ }^{*}=\operatorname{tav}_{n} \sim^{*}=\mathrm{vt}_{n}$ & - \\
\hline 30 & 'name' ${ }_{10}$ & NA a:da, TA *at & & & *kalın & - \\
\hline 31 & new' $_{23}$ & - & & & $*$ =yan & - \\
\hline 32 & 'night' & Nu *awar, TA *war & & & $*=$ zoni & - \\
\hline 33 & 'nose' 29 & - & & ud- & *=min- $\sim^{*}=$ tim- & - \\
\hline 34 & 'not' & $\mathrm{NU}^{*} \mathrm{~m}-, \mathrm{NA} \mathrm{ma}=, \mathrm{TA}^{*} \mathrm{~m}=$ & & & ${ }^{*} z a=\ldots-n$ & - \\
\hline 35 & 'one' $_{21}$ & - & A nala & D anda & ${ }^{*} \mathrm{k}=\mathrm{Id}(\supset)-$ & - \\
\hline 36 & 'rain' 39 & NU *ar-, TA *ar- & & & ${ }^{*} \mathrm{n}{ }^{\top} \mathrm{o}(-) \mathrm{k}$ & $+\mathrm{NNT}$ \\
\hline 37 & 'smoke' 36 & - & A yદši & D losga & ${ }^{*} \mathrm{kI}_{\mathrm{I}}=\mathrm{t} v \mathrm{~m} v(-\mathrm{k})$ & - \\
\hline 38 & 'star' 40 & NU *waje, NA wi:ni, TA *min- & & idi & ${ }^{*}$ quli- & $\pm \mathrm{NNT}$ \\
\hline 39 & 'stone' 9 & - & A mid(i)r & D mbəre & ${ }^{*} \mathrm{k} v \mathrm{r \varepsilon}-\mathrm{t}$ & - \\
\hline 40 & 'sun' & - & *nin & ${ }^{*} \mathrm{n}(\mathrm{I})=\mathrm{onu}(-\mathrm{k})$ & - & \\
\hline
\end{tabular}

Table 2. Comparative 50-item wordlists for Nubian-Nara-Tama, Nyimang, and Temein 


\begin{tabular}{|c|c|c|c|c|c|c|c|}
\hline № & Word & NNT & & \multicolumn{2}{|c|}{ Nyimang } & Temein & Matches \\
\hline 41 & 'tail' 26 & - & & \multicolumn{2}{|c|}{ D weya } & *rın-kak & - \\
\hline 42 & 'thou' & $\mathrm{NU}^{*} \mathrm{e} \sim{ }^{*} \mathrm{i}, \mathrm{NA} \mathrm{I}^{-}$ & a, TA *i- & \multicolumn{2}{|c|}{$*_{\mathrm{i}}$} & ${ }^{*} n=I-n$ & $+\mathrm{NNT},+\mathrm{T}$ \\
\hline 43 & 'tongue' & \multicolumn{2}{|c|}{ NU *nalT-, TA *lana-t } & A nildi & D Jlo & *=kandIma- & $+\mathrm{NNT}$ \\
\hline 44 & 'tooth' & NA nihi, TA *nez- & $\mathrm{NU}^{*}$ nəl- & \multicolumn{2}{|c|}{ *nil- } & $*$ =ay- & $+\mathrm{NNT}$ \\
\hline 45 & 'tree' & \multicolumn{2}{|c|}{ [NA tum 'wood'] } & \multicolumn{2}{|c|}{ *tuma } & *maren & $\pm \mathrm{NNT}$ \\
\hline 46 & 'two' & \multicolumn{2}{|c|}{ NU *awri, NA ari, TA *wari } & \multicolumn{2}{|c|}{ *arba- } & ${ }^{*} \mathrm{k}=$ aro & $+\mathrm{NNT},+\mathrm{T}$ \\
\hline 47 & 'water' 28 & \multicolumn{2}{|l|}{-} & \multicolumn{2}{|c|}{ *bon } & $*=$ mun & $+\mathrm{T}$ \\
\hline 48 & 'we' & \multicolumn{2}{|c|}{ Nu *a-y, NA *a-gga } & \multicolumn{2}{|c|}{ *ay-g- } & ${ }^{*} \mathrm{k}=\mathrm{a}-\mathrm{t}$ & $+\mathrm{NNT},+\mathrm{T}$ \\
\hline 49 & 'what' 12 & \multicolumn{2}{|c|}{ Nu *nwa- *nwi-; TA *num } & \multicolumn{2}{|c|}{ *(a)ni } & *na-i & $+\mathrm{T}$ \\
\hline 50 & 'who' 6 & \multicolumn{2}{|c|}{ NA na-, TA *na; Nu *nə-y } & \multicolumn{2}{|c|}{ *ya- } & *ya-ni & $+\mathrm{NNT},+\mathrm{T}$ \\
\hline
\end{tabular}

Table 2. Comparative 50-item wordlists for Nubian-Nara-Tama, Nyimang, and Temein (continued)

Matches are identified as follows:

- a + between Nyimang and either NNT or Temein indicates a «perfect» phonetic alignment between the reconstructed Proto-Nyimang item and its potential correlate in either Proto-Temein or in one of the three branches of NNT according to the method of Dolgopolsky's consonant classes (the exact same one used in my previous works on the subject, e.g. Starostin 2017);

- a \pm between Nyimang and either NNT or Temein indicates a «plausible» phonetic alignment between the compared items, in that they share a certain degree of phonetic similarity (with at least one out of two consonants which constitute the «consonantal skeleton» of the root belonging to the same Dolgopolsky class) and a credible, if unprovable, scenario to reconcile the differences may be presented (see below notes on such words as 'bird', 'eat', 'star', etc.). Such cases cannot be used as proper lexicostatistical evidence, but ignoring their existence altogether would be imprudent in a clearly long-range comparison.

\section{Detailed analysis of Nyimang entries}

1) 'ashes': $\mathrm{N}^{*}$ finan $\rightarrow \mathrm{A}$ finàn [St.], finān [CR], D fīnín [St., CR].

No matches with either NNT or Temein.

2) 'bird': $\mathrm{N}^{*}$ or-du $\rightarrow \mathrm{A}$ wór [St., CR], D órdō [St.], órdò [CR]. ॥ Second syllable in D is likely suffixal (cf. A kwènì 'knife' = D k(w)ón-dù id.).

Root morpheme *or- may be compared with PNu *kawir- 'bird' (Kenuzi kawir-te, etc.) under the condition that ${ }^{*} k(a)=$ in $\mathrm{PNu}$ is a fossilized prefix (a case of the famous Nilo-Saharan «k-mobile»); in fact, if Nara karba 'bird' also belongs here, this would project the fossilization itself onto the PNNT level. This is a highly speculative scenario, and its acceptance or rejection will depend on further investigation of the issue of possible fossilized morphological elements in NNT languages; nevertheless, the $\mathrm{N}$ form is still closer in shape to NNT than Temein ${ }^{*}=a w \varepsilon$ ( $\mathrm{T} \hat{\imath}=\bar{a} w \dot{\varepsilon}, \mathrm{J} n=\hat{\jmath} i)$.

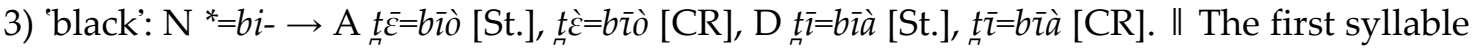
is clearly detachable as a productive dental prefix, seen in many other color terms as well (e.g. A $t \bar{c}=g \bar{\imath} l-\bar{e}$ 'red', A țāebár 'white'). 
No matches with any equivalents in NNT languages (the word is not reconstructible for the PNNT level) or with Temein.

4) 'blood': N *ule $\rightarrow$ A wílì wúlì [St.], wúlí wílí [CR], D ólè [St., CR]. ॥ Word-initial *wdoes not seem to be historically phonological in this case.

No matches with either NNT or Temein.

5) 'bone’: $\mathrm{N}$ *am- $\rightarrow \mathrm{A}$ ám(b)ī [St.], ámí [CR], D á:má [St.], āmá [CR].

This is very clearly the exact same root as in Temein languages ( $\mathrm{T}$ àm-ìs, $\mathrm{J}$ àm-ìk). NNT languages have a completely different set of forms.

6) 'claw (nail)’: ${ }^{*}$ fal- $\rightarrow$ A fálè [St.], fàlì [CR], D fálà [St.], fālá [CR].

This form has no parallels in NNT, but could be compared to the corresponding item in

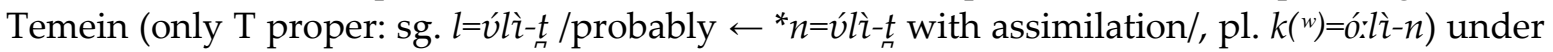
the assumption of contraction from the original stem ${ }^{*} n V=p v i l i$. Without any parallel examples to confirm the possibility of such a contraction, the match is questionable, but should not be ignored altogether.

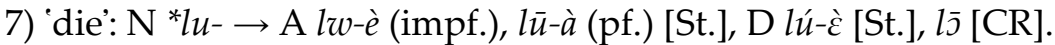

No matches with either NNT or Temein.

8) 'dog’: A gìl [St.], gíl [CR]; D wùl wìl [St.], wúl [CR].

Despite some phonetic similarity, A and D forms cannot be related (no other examples of A $g$ - corresponding to D $w$ - are attested). C. Rilly tentatively suggests a borrowing from $\mathrm{Nu}$ bian into D (which would leave ${ }^{*}$ gil as a better candidate for the proto-level), but this is not very realistic, since the main contacts between $\mathrm{D}$ and Nubian languages involve Hill Nubian idioms, all of which feature a voiced stop reflex for this word (Proto-Hill Nubian *bol 'dog'). A genetic link between D wul and Proto-Nubian *bal 'dog' is, therefore, not out of the question.

9) 'drink': A lì (impf.), tww=il (pf.) [St.]; D dái [St.], daù, imperative daí [CR].

Of these two different roots, the first one is fully compatible with the main NNT root for 'drink' (Nubian ${ }^{*} n i-$-, Nara li:-, Ta ${ }^{*} l i-$, with the regular development ${ }^{*} l-\rightarrow{ }^{*} n$ - in Nubian). Temein *awis- is clearly a completely different root.

10) 'dry’: N *far- $\rightarrow$ A ā=fòr [St.], à=?fór [CR], D fārá-fārà [St.], fārá-fārá [CR].

No matches with either NNT or Temein.

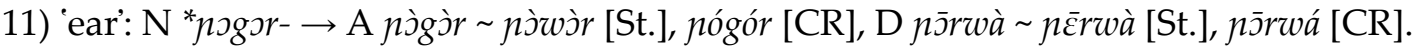

No matches with either NNT or Temein.

12) 'eat': $\mathrm{N}$ *tam- (impf.) $\rightarrow$ A tàm [St.], tām [CR], D țāmàn [St.], tāmán [CR]; "tral- (pf.) $\rightarrow$ A tàl [St.], tāl [CR], D tùll-̀̀ [St.], țāl̀̀ [CR].

The imperfective form *tam- is morphologically unsegmentable; however, the suppletive perfective stem ${ }^{*} t a l$ - may be analyzed as containing the productive perfective prefix $t$ - (see 'drink' above, as well as other examples). In the latter case, the original form of the root may have been either ${ }^{*} a l$ - or * $k a l$-, since root-initial $k$ - is regularly deleted in Nyimang after that prefix (e.g. kai 'to chop' $\rightarrow$ pf. $t=a i, k i w$ 'to dig' $\rightarrow$ pf. $t=i w$, etc.). An original root * $k a l$ - 'eat' would be perfectly compatible with the most common NNT root for 'eat': $\mathrm{Nu}{ }^{*} k \jmath l-, \mathrm{Na} k n l-$. 
13) 'egg': $\mathrm{N}$ *dami $\rightarrow$ A dámì [St., $\mathrm{CR}$ ], D dómì [St., $\mathrm{CR}$ ].

No matches with either NNT or Temein.

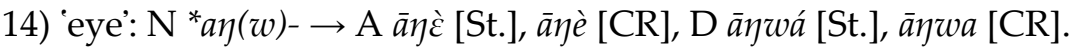

A very transparent correlation with Temein ${ }^{*}=a \eta-\sim^{*}=a$ - $^{-}$'eye' (Temein $n=i$ inínà- $t$, Doni

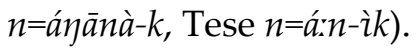

15) 'fire’: $\mathrm{N}^{*}$ mer $\rightarrow$ A mìr [St.], mér [CR], D mbàrr [St.], mbár [CR]. ॥ We follow Rilly’s reconstruction with * $m$ - rather than Bender's with * $m b$ - (based on comparative evidence, it seems that most root structures with resonants such as ${ }^{*} \mathrm{mVr}$ - or ${ }^{*} \mathrm{mVl}$ - regularly dissimilate to ${ }^{*} \mathrm{mbVr}$-/ * $m b V l$ - in D).

No matches with either NNT or Temein.

16) 'foot': A kìrè [St.], kírè [CR]. II This seems a more likely candidate for proto-status than $\mathrm{D}$ māgílà [St.], màg'àlà [CR], a longer and possibly morphologically complex form.

In any case, no matches with either NNT or Temein (the concept 'foot' in general seems to be fairly unstable in most of the area).

17) 'hair’: $\mathrm{N}^{*} y i-\rightarrow \mathrm{A}$ zè [St.], že [CR], D ìyá [St., CR]. ॥ Neither Bender’s proposed reconstruction of * $z E$ nor Rilly's variant *igé seem satisfactory ( $N$ palatal ${ }^{*} z$ is typically preserved in $\mathrm{D}$, and no confirming examples of palatalization ${ }^{*} g \rightarrow z$ in A are attested). We suggest ${ }^{*} y i-$ as the original root, with A reflecting the morphological variant * yi-e and D the morphological variant *yi-a (cf. 'nail' above with precisely such a variation), with affricativization in A (no confirming or disproving examples, since word-initial ${ }^{*} y$ - is in general a rare phoneme in these languages).

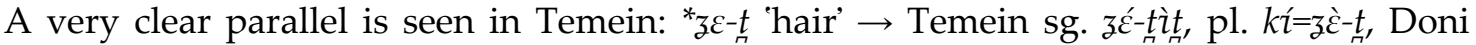
$k i=z \grave{a}-k$, Tese $k \dot{z}=z \grave{a}-k$. Phonetically, the word is closer to A than to D, but if A ze $\leftarrow^{*} y i-e$, this particular proximity may be deemed secondary (indicating either borrowing or independent development).

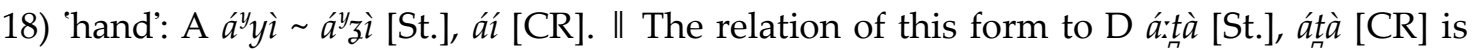
unclear. Rilly suggests reconstructing ${ }^{*} a d i$, but there are no confirming examples of ${ }^{*}-d_{-} \rightarrow-y-$ in A. Alternately, one might think of a suffixal extension in D, e.g. *ay-ta $\rightarrow a(:) t a$, but there is no additional evidence to suggest the existence of such a suffix in Nyimang languages.

On the other hand, this variation is curiously parallel to the one observed in NNT, where $\mathrm{Nu}{ }^{*} \partial-$ si and Tama *aw-g 'hand' reflect an original *ay- *aw-, whereas Nara shows a variant with a fossilized dental suffix (a:t). Temein languages show a completely different situation, with ${ }^{*}=\varepsilon n$ as the most likely protoroot (Temein sg. $n=i n$-àt, pl. $k=\varepsilon ́ n$, Doni sg. $n=a ́ n$-ák, pl. $k=\varepsilon ́ \eta$ ).

19) 'head': $\mathrm{N}$ *or- $\rightarrow$ A wórò [St.], wōrò [CR], D ór [St.].

This is a precise phonetic match with the most widespread NNT root for 'head': Nu *or, Ta *ur. It should be noted that Temein *=vlo 'head' also displays comparable phonetic similarity, but the correlation between $\mathrm{N}^{*} r$ and Temein ${ }^{*} l$ is problematic (both resonants are autonomous phonemes in these language clusters, and no other solid examples of such a potential correspondence are found in our data).

20) 'hear': ${ }^{*}{ }^{*} k i d-~ \sim ~ * k i l-\rightarrow \mathrm{N}$ kin- (impf.), kìl- (pf.) [St.], D kíd-í [St.]. ॥ Although it seems improbable that the listed forms are not related, reconstruction of the original root form is 
problematic; only - $n$ - in N kìn- is clearly segmentable as an imperfective suffix (cf. D impf. kādin according to Rilly), while stem-final $-l$ - and $-d$ - are not known as productive suffixes, nor is this correspondence between $\mathrm{N}$ and $\mathrm{D}$ recurrent or indicative of a special phoneme.

Still, regardless of whether the original root has to be reconstructed as *ki-, ${ }^{*} k i l-$, or *kid-, it can hardly be considered a lexicostatistical match with either NNT or Temein forms.

21) 'heart': $\mathrm{N}_{n}^{*}$ tilum $\rightarrow \mathrm{A}$ túlúm [CR], D tílìm [St.], tílím [CR]. II Note that Stevenson has a different equivalent for A: wílīn $n$ wèl, literally 'house /of/ blood'. In Rilly's notes, A túlúm is actually polysemous (meaning 'heart' as well as 'torso'), and the form tulum is glossed as 'chest' rather than 'heart' in the small wordlist found in MacDiarmid, MacDiarmid 1931: 159.

It is curious to note Rilly's etymology of the A word ās $(\bar{u}) m a ̀ l-i ́ n ~(=\bar{a} s(u) m \bar{a} l i ̀$ [St.]) 'bedbug' as 'little heart' (Rilly 2009: 434); if correct, this is an excellent match with Nara asIma 'heart', but one cannot help but wonder if the internal etymology was directly influenced by the phonetic similarity with Nara; at the very least, evidence from areal semantic typology would be needed to confirm the probability of such an unusual metaphoric development.

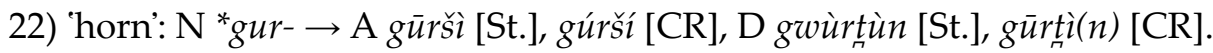

No matches with either NNT or Temein.

23) 'I': $\mathrm{N}^{*} a y \rightarrow \mathrm{A}$ ai $\sim$ a [St.], á ái [CR], D oi woi [St.], oí [CR]. ॥ Labial reflex in D probably under the influence of the genitive stem ${ }^{*} o-u n\left(\leftarrow{ }^{*} a-u n\right.$ ? $)=\mathrm{A}$ wo-un [St.], D o- $\eta-g u$ [CR].

A transparent and extremely important match with NNT (Nu * ${ }^{*}-y$, Na $a-g$ 'I') which explains Bender's placement of Nyimang closer to his «Ek» languages rather than the «En» ones, including Temein (cf. Temein $n=a ́ n$, Doni / Tese $n=a ́ \eta$ 'I').

24) 'kill': $\mathrm{N}^{*} n i \rightarrow \mathrm{A} n \grave{\imath}$ (impf.), $n \bar{\imath}$ (pf.) [St.], D $n \bar{\imath}$ [St.], nìl (impf.), $n \bar{\imath}$ (pf.) [CR].

No matches with either NNT or Temein.

25) 'leaf: A kwồ [St.], D lālūwà [St.]. ॥ The form in D is compared by Bender with A láwà 'grass'; it may be a reduplicated variant denoting a collective meaning.

The contour tone in A kwô may hint at an earlier contraction, which would make the form slightly closer to its Temein equivalent (Temein kóbù-kìt, pl. kābó 'leaf); however, this phonetic alignment would require us to set up the deletion of intervocalic ${ }^{*}-b$ - ( $\left.{ }^{*} k a b s \rightarrow{ }^{*} k a w s \rightarrow k w s\right)$, with no additional examples to support such a development.

26) 'louse’: $\mathrm{N} *(\eta) u n \rightarrow \mathrm{A}$ wìnì [St.], wíní wúní [CR], D ywūnà [St.], ywúnà [CR]. II Initial

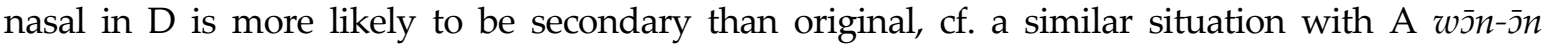
'scorpion' = D ywūn-ák id., where prenasalisation of the glide in D probably appears under the influence of word-medial - $n$-.

No matches with NNT or Temein either way.

27) 'meat': $\mathrm{N}$ *kun $\rightarrow \mathrm{A}$ kwòn kwùn [St.], kwón kwún kún [CR], D kwùn [St.], kún [CR].

No matches with either NNT or Temein.

28) 'moon': ${ }^{*} k(e) w u r \rightarrow$ A kwûr [St., CR], D -kero 'month' (only within compounds, found in Kauczor 1923). II In the basic meaning 'moon', D uses the form ársàn [St., CR] = A ārsá [St.], ársàn [CR] 'sky' (an unusual metonymic development, but more likely than just a coincidence). The archaic stem -kero is impossible to separate from A kwîr, but the exact shape of the proto- 
form is difficult to reconstruct; with the contour tone in A suggestive of an original contraction, *kewur seems like a solid candidate.

The root is somewhat phonetically similar to the main Temein word for 'moon': Temein kóu, Doni kòv?, Tese káù $\leftarrow{ }^{*} k a w$. However, this would require morphological segmentation into ${ }^{*} k e w-u r$, with no easy explanation for the second morphological component.

29) 'mouth’: N *yal $\rightarrow$ A yàl [St., CR], D ygìlà [St.], ygálà [CR]. ॥ D ygìlà may be an erroneous transcription or the result of occasional contamination with ygila 'tooth'.

Vaguely reminiscent of phonetically similar forms in NNT languages $\left(\mathrm{Nu}{ }^{*} a g u l, \mathrm{Na}\right.$ awslo, Ta $\left.{ }^{*} k u l\right)$, but not enough to explain the nasal consonant.

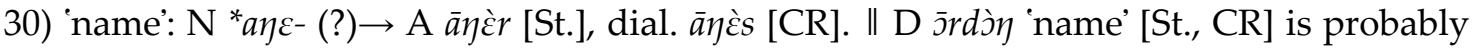
borrowed from a Hill Nubian plural form (cf. Dair sg. or, pl. or-du or-dandu id.). The variation between $\bar{a} \eta \grave{\varepsilon} r$ and $\bar{a} \eta \grave{\varepsilon} s$ in $\mathrm{A}$ is hard to explain by phonetic factors and is probably morphological in origin, leaving ${ }^{*} a \eta(\varepsilon)$ - as the most likely original root for the concept.

No matches with either NNT or Temein.

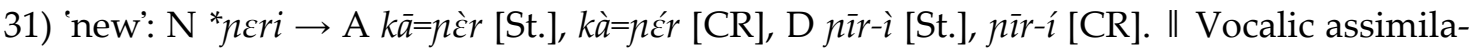
tion in D; original root shape is well preserved in A (augmented by the productive adjectival prefix $k a=)$.

No matches with either NNT or Temein.

32) 'night': $\mathrm{N}^{*}{ }_{n}^{*} u n i \rightarrow \mathrm{A} \underset{n}{\operatorname{tw} w i n}$ [St.], țwín [CR], D túnì [St., CR]. \| Root shape in D is primary, cf. similar developments (assimilative labialization followed by deletion of the final vowel in A) in such examples as D bori 'road' = A bwir id., D oli 'house' = A wel.

Phonetically similar to Temein * =zoni 'night' ( $\rightarrow$ Temein fó: $n$, Doni $\bar{a}=z \bar{u} n i ̀$, Tese fúnì), but no other cases support the recurrence of the correspondence $N^{*} t$ : Temein ${ }^{*}$, so it makes more sense at present to consider the phonetic similarity as accidental.

33) 'nose’: $\mathrm{N}^{*}(a) \eta u d-~ \rightarrow \mathrm{A}$ àmùdù [St.], āmùdù [CR], D ywùtà [St.], ywútí ywútá [CR]. II Initial $a$ - in A remains unclear (more likely to be an obscure morphological component than part of the root). First consonant is reconstructed as ${ }^{*} \eta$ rather than ${ }^{*} m$ because assimilation ${ }^{*} \eta \mathcal{u}^{-} \rightarrow$ $m u$ - is not contradicted by other examples, unlike dissimilation (cf. $\mathrm{N}^{*} m u l$ ' 5 ' $\rightarrow$ A mùl, D mùl id.).

No matches with either NNT or Temein.

34) 'not': A fa. I| Universal negation marker in A. Negation in D is not attested.

No matches with either NNT or Temein.

35) 'one’: A nálà [St.], nálā [CR]; D ándà [St.], ándá [CR]. ॥ For the Mandala dialect of A Rilly gives both forms: nálā 'one', āndá 'only; lonely'; this may have been the original situation, with only one out of two lexemes generalizing both meanings in each language.

No matches with either NNT or Temein.

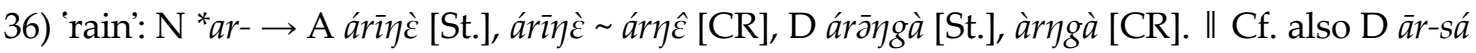

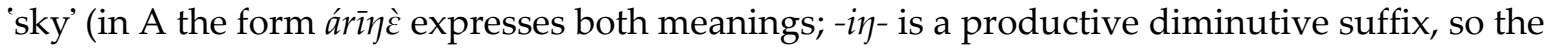
form's original meaning is literally 'little sky' or 'child of the sky').

A transparent match with the most common NNT word for 'rain' ( $\mathrm{Nu}^{*}$ ar-, Ta *ar-). 


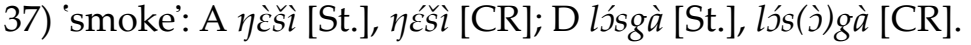

No optimal candidate for Proto-Nyimang status and no matches with either NNT or Temein.

38) 'star’: D mīdí [St.], mādí [CR]. ॥ A kwórš̌̀lè [St.], kūrš̄ilè [CR] is probably a compound form, whose first component (after C. Rilly) is identifiable as kwûr 'moon' (not clear why; if the original meaning of the root was something like 'to shine' or 'light', this would be understandable).

If $\mathrm{D}$ mìli is the more archaic form, a remote resemblance to $\mathrm{Nu}$ *wane, $\mathrm{Na}$ wi:ni, Ta *min'star' may not be accidental (especially if mìdi $\leftarrow{ }^{*}$ min- $d i$ with a fossilized nominal suffix), but the connection must remain highly speculative for now.

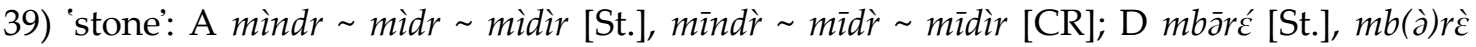
[CR]. I| No clear candidate for proto-status. The form in A is likely to be related to A $m \bar{\varepsilon} d \dot{\varepsilon}$ [St.], $m \dot{d} d_{n} \varepsilon$ [CR] 'mountain', although internal morphology remains unclear.

No matches with either NNT or Temein.

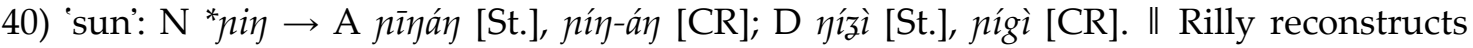
*nig-, but considering that roots with the structure * $N V g$ - do not usually undergo nasal assimilation (cf. nj̀g̀̀r 'ear' above), it would perhaps make more sense to assume dissimilation in D $\left({ }^{*}\right.$ nin- $i \rightarrow$ nig-i).

In any case, no matches with either NNT or Temein regardless of whichever variant of the reconstruction is preferred.

41) 'tail': D wēyá [St.]. II For A, Stevenson records zè 'tail', which is clearly the same word as 'hair' (see above). Unclear if this is a mistake or an actual lexical merger, since alternate sources on A have no data on this word.

D wēyá has no matches with either NNT or Temein.

42) 'thou': $\mathrm{N}^{*} i \rightarrow \mathrm{A} i$ [St., CR], D $i$ [St., CR]. II Interesting suppletivism with the oblique stem in A, cf. genitive case forms - A $n$ - un [St.], $n$ - ̌̌ $[\mathrm{CR}]$. Rilly suggests secondary development of the nasal from an original ${ }^{*} i$ - $и \eta u ~\left(\rightarrow{ }^{*} y u \eta \rightarrow\right.$ nuๆ with assimilation), which seems a plausible explanation, particularly in view of the relative rarity, if not total absence, of such types of suppletivism in other East Sudanic languages.

A clear match with both NNT and Temein, but, once again (see ' $\mathrm{T}$ ), the form is clearly more close to NNT (Nu * $\sim^{*} i$, Na $I-\eta a$, Ta ${ }^{*} i-;$ «Ek» type) than to Proto-Temein ${ }^{*} n=I-n$ («En» type).

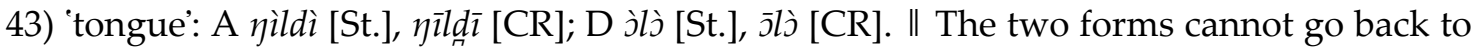
a single source: A may reflect an original * yil- (or * yild-), while D reflects an original ${ }^{*} \mathrm{sl}$ - (or ${ }^{*} \mathrm{ol}$-).

A is clearly compatible with the main NNT root for 'tongue': $\mathrm{Nu}^{*}$ nalT-, Ta *lana-t (the latter with metathesis). Discrepancy in vocalism may be explained by vocalic assimilation in $\mathrm{A}$ ( ${ }^{*}$ yaldi $\rightarrow$ yildi; see 'tooth' below for further comment).

44) 'tooth’: $\mathrm{N}$ * yil- $\rightarrow$ A ilè èlè [St.], ílè [CR], D ygíl [St.], ygílà [CR]. ॥ We follow Rilly in assuming that $\mathrm{A}$ and $\mathrm{D}$ forms are related and go back to an original ${ }^{*} \eta i l-;$ loss of ${ }^{*} \eta$ - before front vowel in A may be regular (no contradicting or supporting examples; cases of attested $\mathrm{\eta i}^{-}$ in A may be interpreted as late assimilations from * $y a$ - before a front vowel in the second syllable, cf. 'tongue' above).

The reconstruction * $y$ il- agrees reasonably well with the main $\mathrm{Nu}$ root for 'tooth' $\left({ }^{*} \mathrm{nal}-\right)$; whether it has something to do with $\mathrm{Na} n i h i$, Ta ${ }^{*} \eta z^{-}$(these forms rather point to an original $\left.{ }^{*} N i g-\right)$ is unclear. 
45) 'tree' : $\mathrm{N}$ *tuma $\rightarrow$ A tómà túmà [St.], túmà [CR], D tīmà [St.], tàmá [CR] 'wood, firewood'. II The meaning '(growing) tree' is today expressed in D by the Arabic borrowing šíāàn [St.], šid̀̀rà [CR].

No lexicostatistical matches with either NNT or Temein, but an obvious, phonetically and semantically perfect comparison is with Na tum 'wood' (this word is still glossed as both 'wood' and 'growing tree' in the old 19th century records of Leo Reinisch).

46) 'two': $N$ *arba- $\rightarrow$ A ár(m)bà [St.], ārbā [CR], D ármàk [St.], ārmàg [CR]. \| Cf. also Mandala $\bar{a} r m b a ̀ ~[C R]$. It is not quite clear if all the attested variants ultimately go back to *arba- or *arma-, but whatever the case, phonotactic structure of the form speaks in favor of an original root *ar-, extended with a suffixal component (either -ba- or -ma-).

A solid match with both the NNT root for 'two' ( $\mathrm{Nu}$ *awri, $\mathrm{Na}$ ari, $\mathrm{Ta}$ *wari) and the Temein form (Proto-Temein ${ }^{*} k=$ aro, with a productive numeric prefix). It is possible that the labial element cropping up in both $\mathrm{Nu}$ and $\mathrm{Ta}$ is actually the same as in $\mathrm{N}$, indicating an original ${ }^{*} a r-b$ - or *ar-w-.

47) 'water': $\mathrm{N}^{*}$ bo $\rightarrow \mathrm{A}, \mathrm{D}$ bón [St., CR].

No matches in NNT, but clear phonetic similarity with Temein: Proto-Temein ${ }^{*}=m v \eta(T e-$ mein $m \dot{v} \eta$, Doni $\bar{a}=m \bar{v} \eta$, Tese $\bar{\imath}=m \dot{v} \eta \sim \bar{v}=m v ́ \eta)$.

48) 'we’: $\mathrm{N}^{*}$ ay-g- $\rightarrow$ A ayi [St.], āyí [CR], D ogo [St.], ógj̀ [CR]. \|| Rilly reconstructs *agi. Labial vowel in $\mathrm{D}$ is likely due to analogical leveling with the rest of paradigm, cf. genitive case: A wón, D óu $[\mathrm{CR}] \leftarrow{ }^{*} a y$ - $g$-un (labialisation first spreads to the root through assimilation with the suffixal vowel, then becomes generalized across the entire paradigm).

The root morpheme here is the same as in 'I', and the reconstruction *ay-g-is much closer in structure to NNT ( $\left.\mathrm{Nu}{ }^{*} a-y, \mathrm{Na}{ }^{*} a-g g a\right)$ than to Temein (Proto-Temein ${ }^{*} k=a-t$ 'we', with the same original root but in a completely different morphological configuration).

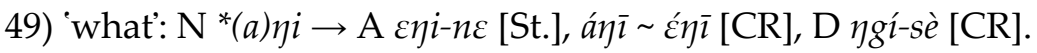

The morpheme ${ }^{*} \eta i$ is extremely similar to Temein material (Temein $\eta \bar{\varepsilon}$, Doni $\eta \bar{\varepsilon}$, Tese $\eta \bar{e} \bar{\imath}$ ); NNT forms (Nu *nwa- *nwi-; Ta *num) also share some phonetic similarity but are clearly more distinct.

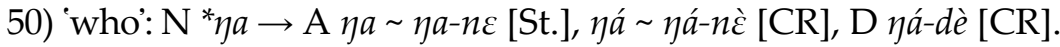

This root is fully compatible with both Temein forms (Temein $\eta a ́-n \bar{\imath}$, Tese $\eta \bar{a}-n \dot{\varepsilon}$, where the second morpheme is the root 'person') and with NNT (especially Nu ${ }^{*} \eta \partial-y$ ).

\section{Analysis}

Let us now summarize the results of Nyimang / NNT / Temein comparison (Table 3), paying particular attention to «perfect» matches («plausible» matches may not be taken into serious consideration at this stage of analysis).

\begin{tabular}{|c|c|c|c|}
\hline \multicolumn{2}{|c|}{ Nyimang matches with NNT } & \multicolumn{2}{|c|}{ Nyimang matches with Temein } \\
\hline+ & \pm & + & \pm \\
\hline 12 & 4 & 9 & 3 \\
\hline $\begin{array}{l}\text { 'dog', 'drink', 'hand', 'head', 'I', 'rain', } \\
\text { 'thou', 'tongue', 'tooth', 'two', 'we', 'who' }\end{array}$ & $\begin{array}{l}\text { 'bird', 'eat', } \\
\text { 'star', 'tree' }\end{array}$ & $\begin{array}{l}\text { 'bone', 'eye', 'I', 'thou', 'two', } \\
\text { 'water', 'we', 'what', 'who' }\end{array}$ & $\begin{array}{l}\text { 'claw/nail', 'hair', } \\
\text { 'moon' }\end{array}$ \\
\hline
\end{tabular}

Table 3. «Perfect» and «plausible» matches between Nyimang and NNT / Temein. 
It may be seen that, although Nyimang/ NNT matches are encountered somewhat more frequently than Nyimang / Temein matches, the prevalence is not significant enough by itself for us to conclude that the former are indicative of genetic relationship and the latter of contact. However, it is important to note that 6 out of 9 "perfect» matches between Nyimang and Temein are non-exclusive, with only 'bone', 'eye', and 'water' not being shared with Nyimang; conversely, 7 out of 12 (more than half) matches between Nyimang and NNT have no parallels in Temein. Finally, it will be quite clear from Table 2 that almost no additional isoglosses can be detected between Temein and NNT to the inclusion of Nyimang, making a subgrouping of «NNT + Nyimang + Temein» quite unrealistic.

How should such a contradictory picture be resolved? The first impulse would be to ascribe all exclusive Nyimang/ Temein isoglosses to linguistic contact between two neighbouring groups in the Nuba Mountains. However, an alternate solution exists as well, suggesting itself once the statistical results between Nyimang and NNT are contrasted with similar results between the branches of NNT itself. According to Starostin 2017: 109, NNT languages share from at most 18 matches on the 50-item wordlist (between Nubian and Tama) to at least 13 matches (between Nubian and Nara). Nyimang, conversely, has at most 12 matches (all of them with Nubian) and at least 7 (with Nara). This means that Nyimang cannot be considered properly a part of NNT, but could be considered as an earlier offshoot:

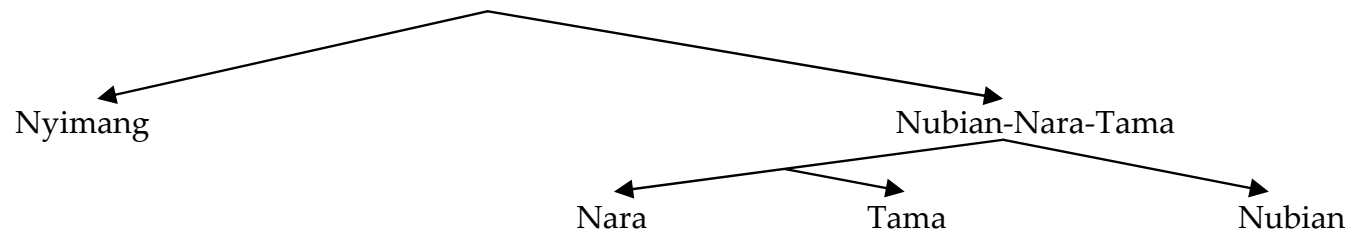

If this is the case, and the entire grouping itself is a subbranch of the even larger East Sudanic family, this puts Nyimang languages in a position where they could, at least in theory, preserve a number of archaisms inherited from East Sudanic that would be replaced by innovations on the level of Proto-NNT. These archaisms, in turn, could also be preserved in Temein - meaning that the several links we see between these groups might actually be «shared archaisms» rather than «shared innovations» (either through common inheritance or contact).

This issue, unfortunately, cannot be resolved without bringing into comparison data from other potential branches of East Sudanic; however, even if such an expansive comparison in general is way beyond the scope of the current paper, a few preliminary observations can still clarify the picture. Specifically, of the three exclusive isoglosses between Nyimang and Temein at least two show strong connections with other branches of East Sudanic:

(a) 'bone': to Nyimang *am-, Temein *am- one should also add Surmic: Proto-Southwest Surmic * ${ }^{*} m m \varepsilon-\left(\right.$ more likely, ${ }^{*} a m m \varepsilon-$ ) + Majang (North Surmic) $\varepsilon m \varepsilon-n a n$ (Yigezu 2002: 258; Starostin 2014: 118), and possibly also parallels in the Jebel languages: Proto-Jebel * $g$ )am (Bender 1998: 55). In terms of distribution, this is a very strong candidate for 'bone' in Proto-East Sudanic, meaning that the forms in Nyimang and Temein may simply be retentions from a faraway common ancestor;

(b) 'eye': to Nyimang ${ }^{*} a \eta(w)-$, Temein ${ }^{*}=a \eta-\sim^{*}=a n$ - one should necessarily add Proto-Daju

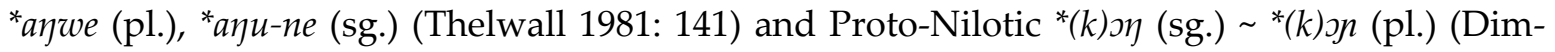
mendaal 1988: 40). Without a doubt, this is the main «Southeast Sudanic» (Bender's «En») root for 'eye', and it is quite plausible to suggest that it was also retained in Nyimang, but replaced in NNT with an innovation.

Only the 'water' isogloss presents a really special case. Although phonetically similar forms with an initial labial nasal are well attested in other East Sudanic languages as well, e.g. 
Proto-Daju *ma- (Thelwall 1981: 159), Proto-Southeast Surmic * ma and Proto-Southwest Surmic *ma:m (Yigezu 2002: 283, 314), it is not clear if they are really the same root as Nyimang *boy, Temein ${ }^{*}=m v \eta$, and even if they are, the latter forms clearly show more affinity to each other, as far as morphological structure is concerned. However, one possible shared innovation on the entire list is certainly not enough to skew the case towards the scenario of a close relationship between Nyimang and Temein.

As for the exclusive isoglosses between Nyimang and NNT, no fewer than five of those are truly exclusive: 'dog', 'drink', 'head', 'rain', 'tooth' are all items which find no correlations (at least, not direct lexicostatistical correlations with the same Swadesh meaning) in any other potential branches of East Sudanic. Only 'hand' reflects a rather common East Sudanic root. This observation, coupled with the fact that even personal pronouns such as ' $\mathrm{I}$ ' and 'thou' are morphologically closer to their NNT equivalents than Temein (and «En» language in general), speaks very strongly in favor of Nyimang and NNT sharing an exclusive common ancestor.

It must be stated that, since the comparison between Nyimang and NNT as presented here relies on phonetic similarity (more precisely, phonetic alignment based on Dolgopolsky's consonant classes) rather than phonetic correspondences, it is perfectly possible that some real etymological cognates have escaped detection; a small hint at that is provided by "plausible» matches such as 'bird' or 'to eat', where cognacy may have been obscured by the introduction of morphological markers. Conversely, it is also possible that at least a few of the detected «cognates» between Nyimang and NNT are, after all, the result of secondary contact (e.g. 'dog'). But a genetic explanation of the similarities still seems preferable, if only because the distribution of cognates in accordance with their «average stability rank» shows that, out of 12 potential matches, an overwhelming 10 are found in the upper half of the 50-item wordlist's stability index and only 2 ('head ${ }_{49}{ }^{\prime},{ }^{\prime} \operatorname{rain}_{39}{ }^{\prime}$ ) are from the lower half - a clear sign of genetic relationship.

Of course, it is doubtful that the Nyimang / NNT relationship will be supported in the future by an impressive number of etymologies (numbering in the hundreds): lexicostatistical results such as these indicate significant depth of divergence, and since Ama and Dinik are just two relatively close modern languages represented by modest-size wordlists rather than large dictionaries and text corpora, preserved lexical cognates are bound to be few. However, at this stage of research it may be stated with relative certainty that a solid enough case has been built up for ascertaining the East Sudanic (even more precisely, Northeast Sudanic) status of this little group, and that it is highly unlikely that a more solid case will ever be built up for changing this affiliation to something completely different.

\section{References}

Bender, Lionel M. 1998. The Eastern Jebel Languages of Sudan II. Comparative Lexicon. Afrika und Übersee 81: 39-64.

Bender, Lionel M. 2005. The East Sudanic Languages: Lexicon and Phonology. Southern Illinois University: SIU Printing/Duplicating.

Dimmendaal, Gerrit J. 1988. The lexical reconstruction of proto-Nilotic: a first reconnaissance. Afrikanistische Arbeitspapiere 16: 5-67.

Dimmendaal, Gerrit J. 2018. On stable and unstable features in Nilo-Saharan. In: Helga Schröder, Prisca Jerono (eds.). Nilo-Saharan Issues and Perspectives: 9-23. Köln: Rüdiger Köppe.

Ehret, Christopher. 2001. A Historical-Comparative Reconstruction of Nilo-Saharan. Köln: Rüdiger Köppe Verlag. Greenberg, Joseph H. 1966. The Languages of Africa. Bloomington, Indiana University; Mouton \& Co., The Hague.

Kauczor, P. Daniel. 1923. The Afitti Nuba of Gebel Dair and their relation to the Nuba proper. Sudan Notes and Records 6: $1-34$.

Kauczor, P. Daniel, Albert Drexel. 1930. Die Daiersprache in Kordofan. Bibliotheca Africana 4/1: 67-78, 4/2: 42-53. 
MacDiarmid, P. A., D. N. MacDiarmid. 1931. The languages of the Nuba Mountains. Sudan notes and records 14: 149-162.

Meinhof, Carl. Sprachstudien im egyptischen Sudan. 17. Kudugli. 18. Kurungu. 19. Nyima. Zeitschrift für Kolonialsprachen VII: 326-335.

Rilly, Claude. 2009. Le Méroïtique et sa famille linguistique. Louvain - Paris - Dudley, MA: Peeters.

Starostin, George. 2010. Preliminary lexicostatistics as a basis for language classification: a new approach. Journal of Language Relationship 3: 79-117.

Starostin, George. 2014. Jazyki Afriki: Opyt postrojenija leksikostatisticheskoj klassifikacii. Tom II: Vostochnosudanskije jazyki. Moskva: Jazyki slav'anskoj kul'tury.

Starostin, George. 2017. Lexicostatistical Studies in East Sudanic I: On the genetic unity of Nubian-Nara-Tama. Journal of Language Relationship 15/1-2: 87-113.

Stevenson, Roland C. 1957. A survey of the phonetics and grammatical structure of the Nuba Mountains languages, pp. 3-5. Afrika und Übersee 41: 27-65, 117-152, 171-196.

Stevenson, Roland C. 1978-1979. Teisei umm Danab Work sheets. Ms., available at: http://www.rogerblench.info.

Stevenson, Roland C. 1978-1986. Wordlists of Keiga Jirru. Ms., available at: http://www.rogerblench.info.

Stevenson, Roland C. 1981. Adjectives in Nyimang, with Special Reference to $k$ - and $t$ - Prefixes. In: Thilo C. Schadeberg, M. Lionel Bender (eds.). Nilo-Saharan: Proceedings of the First Nilo-Saharan Linguistics Colloquium, Leiden, September 8-10, 1980: 151-165. Dordrecht \& Cinnaminson: FORIS Publications.

Stevenson, Roland C. 1988. Temein work sheets. Ms., available at: http://www. rogerblench.info.

Stevenson, Roland C. 2000. Roland Stevenson's Nyimang and Dinik Lexicon. Ed. by M. Lionel Bender. Afrikanistische Arbeitspapiere 63: 103-120.

Stevenson, Roland C., Franz Rottland, Angelika Jakobi. 1992. The verb in Nyimang and Dinik. Afrikanistische Arbeitspapiere 32: 5-64.

Thelwall, Robin. 1981. The Daju Language Group. Systematic Phonetics, Lexicostatistics and Lexical Reconstruction. D. Phil. School of Humanities of the New University of Ulster.

Voogt, Alex de. 2009. A sketch of Afitti phonology. Studies in African Linguistics 38(1): 35-52.

Yigezu, Moses. 2002. A comparative study of the phonetics and phonology of Surmic languages. Thèse de doctorat. Laboratoire de phonologie, Université libre de Bruxelles.

Yip, May. 2004. Phonology of the These language. Occasional Papers in the Study of Sudanese Languages 9: 93-117.

Г. С. Старостин. Лексикостатистические исследования по восточносуданским языкам II: статус языковой группы ньиманг

Публикация продолжает серию исследований автора, посвященных лексикостатистическому обоснованию языкового родства между целым рядом мелких групп и крупных семей, традиционно объединяемых в рамках так называемой «восточносуданской» семьи. В данной статье проводится сопоставительное исследование базисной лексики языков ньиманг, локализированных в районе гор Нуба (Кордофан), и лексики нубийско-нара-тама ветви восточносуданской семьи, а также лексики соседних по отношению к ньиманг языков темейн. Показано, что данные свидетельствуют скорее в пользу ближайшего языкового родства между ньиманг и нубийско-нара-тама ветвью, в то время как параллели между ньиманг и темейн следует скорее объяснять отчасти вторичными контактами, отчасти - более отдаленным родством в общих рамках восточносуданской семьи.

Ключевые слова: восточносуданские языки; нубийские языки; нара язык; тама языки; темейн языки; лексикостатистика; базисная лексика. 